ZESZYTY NAUKOWE UNIWERSYTETU SZCZECIŃSKIEGO

NR 884

EKONOMICZNE PROBLEMY USŁUG NR 119

2015

DOI: 10.18276/epu.2015.119-07

\author{
Michał Pluciński*
}

\title{
THE TRANSFORMATION OF THE PORT INDUSTRY PLANTS WITH THE AIM OF INCREASING THE IMPORTANCE OF SERVICES. CASE STUDIES
}

\begin{abstract}
A traditional group of port industry plants which operate in seaports, including the biggest Polish seaports, is made up of the plants importing cheap raw materials by sea. With a direct access to sea transport they use the so-called "scale effect". Since the commencement of the system transformation in Poland these plants have been undergoing organizational, proprietary and functional alterations. One of the most important directions of these changes has been an increase in the importance of services in the functioning of the plants. What is manifest in the case of the fertilizer companies from Police, Gdańsk and Szczecin is that they have been developing their services in order to meet both their individual and external entities' needs, although their industrial operations are still predominant. However, the remaining plants situated in the Polish seaports and analyzed in this article have changed their business activity from industrial operations to services. They have gradually abandoned production and replaced the handling which was carried out solely to meet their individual needs with the development of services provided to external customers and new merchandise. This process has been taking place in relation to the Baltchem, the Siarkopol Gdańsk and the formerly operational Huta Szczecin. It is
\end{abstract}

* Michał Pluciński, Associate Prof., PhD, University of Szczecin, Faculty of Management and Economics of Services, e-mail address: michal.plucinski@wzieu.pl. 
reasonable to predict that in the future the Polish port industry sector will exhibit growing tendencies towards the increasing importance of:

- services complimentary to industrial operations,

- services provided to external entities,

- situation in which external investors, primarily in the services sector, will operate on the port land which is not used by the ports in order to meet their individual needs,

- replacing industrial operations with services.

Keywords: port industry, port services, system transformation

\section{Introduction}

The industrial function is one of the most important economic functions of seaports. A traditional group of industry plants launching their operations in seaports include plants importing raw materials whose weight is lost considerably in the course of a production process, which results in a certain cost reduction in relation to transport of ready-made goods. In such a case a seaport is regarded as a locality situated in the closest vicinity to the market which supplies cheap raw materials. If ready-made goods manufactured in these plants are exported by sea or purchased in a port or port town, transport cost savings are two-fold (Luks 2009: 200).

With the example of particular Polish seaports it is possible to observe changes taking place within this group of industrial entities. They include:

- transformations occurring within the framework of their industrial function,

- development of industrial operations performed with the aim of establishing industrial and service complexes,

- discontinuation of industrial operations for the sake of services.

It is the transformations mentioned in the last two points that the author addresses in this article. 


\section{Theoretical aspects}

The economic system transformation which Poland has been undergoing since the beginning of the 1990s involves permanent structural changes. What is defined as a structural change is the "conversion" of economies into more thriving sectors which, because of their high productivity level, stimulate their development and therefore contribute to modifications of the existing economic structures (Karpiński 2008: 6). These changes can be analyzed in relation to the entire Polish economy or its specific areas.

What, for the most part, shaped the directions of the transformation taking place in the Polish economy was the so-called tri-sectoral theory, popularized in the 1980s and 1990s. According to this theory, an economic development is viewed in the context of changes occurring in three main sectors of economy. The subsequent approaches to structural analyses aimed at increasing the level of study disaggregation and achieving a level of more detailed information (Kołowski, Wysocki 2012). According to M. Klamut, the structural changes taking place in economy are so complex that they should be studied in the increasingly disaggregated arrangements (Klamut 1996).

Apart from the considerations made in relation to the inter-sectoral or interbranch arrangements structural changes can be studied within the inside-branch arrangement (see example Pluciński 2013: 157 et seq.). Such an arrangement, studied here in detail, is the transformation of the port industry plants situated in the areas belonging to the biggest Polish seaports. This transformation involves developing services regarded as operations accompanying industrial operations or even replacing industrial operations with services.

\section{Case study}

\section{Grupa Azoty Zakłady Chemiczne „Police” SA}

Grupa Azoty Zakłady Chemiczne „Police” SA (formerly known as Zakłady Chemiczne „Police”) is the top company both within the Polish and international chemical market as well as a leader in the sector of artificial fertilizers and titanium white (Grupa Azoty 2015). It is also the only example of an industrial plant in Poland having an entire seaport under its management. With regard to the 
volume of annual handling, the port of Police comes as the fifth seaport in Poland (Mańkowska 2010:179-189).

The port operations in Police are performed at three terminals including: „Morski”, „Barkowy” and „Mijanka” (Kotowska, Mańkowska, Pluciński 2009). Until now the transport function in this port has been mainly fulfilled for the purpose of the local chemical plants. The port of Police has specialized in handling bulk cargo including phosphorites, apatites, ilmenite ore, sylvinite, fertilizers, ammonia and sulphuric acid. So far the operations performed for external customers have been troubled by the priority of handling the local chemical plants.

There are two separated handling stations operating at the „Morski” terminal:

- one for unloading phosphate raw materials where craft of up to $215 \mathrm{~m}$ in length ( $31 \mathrm{~m}$ in width) with a draught of up to $9.15 \mathrm{~m}$ can moor,

- and another one for loading fertilizers where craft of up to $200 \mathrm{~m}$ in length ( $31 \mathrm{~m}$ in width) with a draught of up to $9.15 \mathrm{~m}$ can moor.

At the "Bankowy" terminal where sylvinite, ilmenite and slag are unloaded and fertilizers loaded it is possible to handle vessels of up to $120 \mathrm{~m}$ in length with a maximum draught of $3.7 \mathrm{~m}$. At the "Mijanka" terminal where ammonia and sulphuric acid are loaded vessels of up to $140 \mathrm{~m}$ in length with a draught of $8.7 \mathrm{~m}$ are handled (Jarmarczysk, Rzempała 2014).

Since the beginning of 2005 a company called Police Port Authority has been managing the port of Police. By fulfilling one of its most important statutory tasks ZMPP has initiated the production of a document including the directions of the development of the port of Police by 2020 (2006). The mission of the Police port as formulated in "Strategia rozwoju morskiego portu Police w latach 20062020 " "The Strategy for the Development of the Seaport of Police from 2006 to 2020 "), clearly indicates the direction of the functional and spatial transformation of the port. According to this mission, the port of Police is supposed to reach and maintain the position of a modern, versatile and reliable seaport which provides efficient, fast and trusty services for means of transport and merchandise as well as play a role of an efficient link in the logistic transport chain and a stimulant of the development of the local entrepreneurship. The key tasks identified in this document also emphasize the necessity to extend the existing services range towards handling cargo (dry and liquid bulk cargo as well as general cargo) which has never been existent in the port of Police (Zarzecki 2006). The investment actions included in "A Strategy..." have been divided into 3 stages. The first in the plan 
is the fulfillment of the investment in the area located to the north of the "Morski" terminal as well as the construction of the roads and railway infrastructure leading to the "Morski" terminal. The main investment at stage 2 is supposed to be the development of 30 ha of land to the south of the existing "Morski" terminal and at stage 3 - the fulfillment of the investment in the area adjacent to the "Barkowy" terminal. Apart from the investments made by the local chemical plants it is also external customers who are supposed to play a key role in fulfilling the provisions of "A Strategy...". Because of this approach, the port of Police stands a chance of transforming from a factory port into a full access port.

The study entitled "The Determinants and Directions Towards Activation of the Port Area Situated to the North of the Morski Terminal at the Port of Police" (Kotowska, Mańkowska, Pluciński 2009) is devoted to the subject of developing the area of the port of Police whose preparation for new investments is the best. What is new in relation to the deliberations included in the previously mentioned document is an in-depth analysis of the models of investment in the port infrastructure which are commonly applied worldwide. The deliberations are finished with a formulation of actions desired by the Police Port Authority, leading to providing a competitive product and services range for potential investors.

The role of port operations will also be of greater importance in the context of the development plans of the chemical conglomerate plants in Police. In 2019 a new propylene plant is supposed to be set up in Police. Its annual output capacity will be at the level of 400 thousand tonnes. It is intended in the project, with a value of PLN 1.7 billion, to construct an installation for propylene production, build an energy block as well as extend the port of Police with a terminal for liquid chemicals. LPG for production will be supplied by sea, but ready-made products will be transported to the customers by ship and barge. According to the investor's estimates, approximately $60 \%$ of the production will be for export or used in subsequent installations. The remaining volume will be sold within Grupa Azoty, including the plant in Kędzierzyn whose whole demand for propylene will be then met.

The most important determinants, which will influence the development of the operations performed by the port of Police, include the fulfillment of:

- project aimed at deepening the Świnoujście waterway down to $12.5 \mathrm{~m}$,

- investments aimed at providing Odrzańska Droga Wodna (the Oder Waterway) with the parameters of at least the third navigational class within the entirety of its course (ultimately, at least the fourth navigational class). 
The deepened waterway will allow to accept bigger craft, which - as roughly estimated - will allow to increase particular deliveries by 4,000-8,000 tonnes and decrease the fees by 1.5-3 USD (Jarmarczysk, Rzempała 2014). This will certainly result in a bigger interest in the port of Police by potential cargo administrators and investors. Even if the investments in the road and railway infrastructure at the "Morski" terminal ${ }^{1}$ planned in "A Strategy..." are not fulfilled, the navigational Odrzańska Droga Wodna will allow to provide efficient drop-off/pick up of cargo from/to the port of Police at the side of the supply base. In order to quicken the process of opening the port of Police to external investors, who are primarily connected with the services sector, a huge role can be also played by construction of the west ring road together with the Police - Swięta crossing which has been planned for years.

The remaining examples: Gdańskie Zakłady Nawozów Fosforowych 'Fosfory" sp. z o.o., Fosfan SA, Baltchem SA, Siarkopol Gdańsk SA, Huta Szczecin SA

Within its own land a Gdańsk-based fertilizer company called "Fosfory" combines the tasks of a managing entity and a commercial entity aiming at profit maximization. The company has a wharf called "Chemików" (240 $\mathrm{m}$ in length with a maximum draught of $10.2 \mathrm{~m}$ ) and another one called "Chemików Nowe" (130 $\mathrm{m}$ in length with a maximum draught of $7.8 \mathrm{~m}$ ). It also makes use of the "Przemysłowe" wharf which belongs to the Gdańsk Port Authority (205 m in length with a maximum draught of $7.05 \mathrm{~m}$ ) (Fosfory 2015). "Fosfory" does not run their handling and storage operations independently. Its wharves together with the handling equipment are leased out to a handling company "Chemiki". It also used their location within the port of Gdańsk for providing forwarding services and arranging handling and storage services mainly for other chemical industry plants situated on the mainland. The handling and storage operations are performed on the basis of the terminals dedicated to liquid cargo (molasses, lye, sulphuric acid, phosphoric acid) as well as dry cargo (fertilizers and soda ash) (Zakłady Nawozowe Fosfory 2013).

A similar strategy in relation to its own commercial activity, i.e. extension of its primary industrial activity with the services performed for external custo-

The potential demand for water transport services in relation to the port of Police includes 260,000 tonnes/year of Silesian coal and 170,000 tonnes of the chemical products from Grupa Azoty Zakładów Azotowych Kędzierzyn - Koźle SA which are now sent by sea via the port of Szczecin (Jarmarczysk, Rzempała 2014). 
mers, has been adopted by "Fosfan" - a producer of agricultural fertilizers with its premises in the area belonging to the port of Szczecin. The company promotes handling and storage, which was only performed to meet its individual needs in the past, under the name "Port nad Odrą". The "Port nad Odrą"complex includes a concrete wharf which is $246 \mathrm{~m}$ in length, with a permissible draught of $5.8 \mathrm{~m}$ and a dolphin wharf which is $185 \mathrm{~m}$ in length. Until recently, the first wharf was able to handle craft with maximum 3,000 DWT. After the modernization completed in 2015 Fosfan will be able to increase the depth by the concrete wharf to $7.5 \mathrm{~m}$. This will make it possible to unload craft with 8,000-10,000 DWT.

Apart from the handling performed for sea craft, Fosfan also uses the handling wharves for handling river barges. Apart from handling and storage services dedicated mainly to loose and liquid chemical cargo as well as aggregates, Fosfan makes it possible for external investors to be involved in development of a handling and storage potential for loose and liquid chemical cargo (Zakłady Nawozowe Fosfan 2013).

Before 1998 another Szczecin-based company, the Baltchem, was a paint manufacturer for the shipyard industry. From the beginning of the 1970s in the twentieth century to the mid-1980s it also produced coal and coke tar. Until 2008 it also refined vegetable oils used for industrial purposes. The privatization of the most important paint manufacturers in Poland and its redirection towards foreign markets supplying resin for paint production urged the Baltchem to:

- discontinue its industrial activity with the aim of extending its transport function with handling external entities,

- give access for external entities to the vacant land for terminal investments (for example, an investment of a Scandinavian company, Nynass, in the port of Szczecin),

what was necessary for fulfilling a new strategy is the development of the then port potential encompassing both the port of Szczecin and Świnoujście.

The Baltchem port terminals are situated in (Baltchem 2015):

- Szczecin, at Kujota St. - with an area covering 41,519 m²; it has its own handling and stopping wharf which is $330 \mathrm{~m}$ long in total, with a maximum draught of $6.5 \mathrm{~m}$; petroleum products, methanol, ethanol, raw vegetable oils and other liquid products are handled within its area,

- Szczecin, at Górnośląska St. - with an area covering 35,309 $\mathrm{m}^{2}$ where 8,0002 is on a 25 -year lease agreement signed with the NYNAS company whose area of business is asphalt distribution; there is no possibility for craft to moor directly at the wharf, 
- Świnoujście, at Karsiborska St. - covering an area of 107,417 $\mathrm{m}^{2}$; it has a handling wharf which is $272 \mathrm{~m}$ long in total and equipped with 2 handling stations for tankers and barges; it can handle craft with a maximum draught of $8.5 \mathrm{~m}$; the terminal has 11 underground tanks with a maximum volume of $72,200 \mathrm{~m}^{3}$.

It is assumed at the Baltchem that the fulfillment of new investments will be carried out on the basis of the long-term agreements signed with customers for handling and storage services related to a specified cargo group (Baltchem 2013). As regards the area at Górnośląska St., the Szczecin Baltchem is interested in the cooperation with external investors who would carry out their investments in that area.

In 2015 the Baltchem won a competition for leasing and buying out (optionally) the inland port of Kędzierzyn-Koźle. The investment has been divided into stages. First, a liquid bulk cargo terminal together with the infrastructure for rail and road tanks as well as inland shipping will be constructed. Then, a container terminal as well as loose cargo terminal will be built.

Before the 2010s the operations performed by Siarkopol Gdańsk which conducts its business in the area of 52 ha within the land belonging to the port of Gdańsk were also in relation to the fulfillment of the industrial function (liquid sulphur granulation). What was complementary to this function is the fulfillment of the transport function related to handling cargo on the mainland and the storing of sulphur transported from the Polish mines. Due to no direct access of the area where the Siarkopol Gdańsk operates to the port wharf the handling of services on the water is provided by Siark-Port (a wharf of $275 \mathrm{~m}$ in length with a maximum draught of $10.2 \mathrm{~m}$ ). What put an end to the sulphur mining industry is the market captured with a great amount of much cheaper residual sulphur coming from the crude oil and natural gas desulphurization. For the Siarkopol Gdańsk, which for decades was the main sulphur exporter from Poland and at the same time an entity which dealt with granulation of sulphur brought in a liquid state from the Polish mines, the sulphur granulation which had started in the mines also brought about an unfavourable change. If we add that sulphur mining in the Polish mines is scaled down practically to a level of the domestic demand made primarily by the chemical industry plants, the functional transformation of the Siarkopol Gdańsk has turned out to be necessary. The new determinants have forced the company to perform actions with the aim of: 
- abandoning its industrial operations in relation to sulphur granulation (January 2005),

- diversifying handling services,

making external entities interested in launching their business operations in its area (Siarkopol Gdańsk and Siark-Port 2013).

In the course of the functional diversification programme the Siarkopol Gdańsk developed its capacity to store sulphur and other liquid products as well. As a result, the following specialized terminals have been constructed in the area of the company (Siarkopol Gdańsk, 2015):

- handling and storage terminal for sugar beet or sugar cane molasses, interchangeably,

- handling and storage terminal for "heavy" burning oil,

- handling and storage terminal for "light" burning oil,

- handling terminal for vegetable oils in import,

- handling installation for base oils in a direct relation.

Additionally, in response to the expectations held by the market partners since 2012 the company has been providing the handling carried out by way of intermodal means of transport, including flexi-tanks and flexi-bags.

By the late 19th century the Huta Szczecin had a direct access to sea transport in the port and industrial area located in the district of Stołczyn in the north part of the port of Szczecin. The plant with an annual output at a level of 200,000 tonnes specialized in producing a wide range of pig iron varieties for the purpose of the foundry. As a result of the unsuccessful attempts to reactivate its production operations, in 2008, the plant's last owner, the Kronospan company, was forced to liquidate its industrial activity.

The revitalization of this part of Szczecin port has been carried out similarly to what happened in the case of the Baltchem and the Siarkopol, i.e. by way of stimulating its transport function and was related to the development of the following parts of the port of Szczecin (Krono-Chem 2013):

- terminal dedicated to handling liquid raw materials for the needs of Kronospan concern,

- public terminal, which handles cargo for external contractors, specializing in handling iron ore for the consignees in Poland and abroad and other dry bulk cargo including coal and chemical merchandise.

At the moment the port operations in the area belonging to the former Huta Szczecin are carried out by the company Alfa Terminal Szczecin Ltd. The com- 
pany has a wharf which is $421,90 \mathrm{~m}$ long with a maximum draught of $8 \mathrm{~m}$ as well as the rail and road infrastructure.

The public nature of the Alfa Terminal Szczecin is primarily manifested in its openness to provide the handling and storage as well as manipulative services in relation to the merchandise of entities different to the Kronospan concern, performed under the "Bulk Cargo Handling Base".

\section{Summary}

Bearing in mind the results of the analyses, a number of the most tangible conclusions can be formulated.

1. The industrial function has played a huge role in the development of the 2 nd generation seaports. In the subsequent stages of their development this function can be developed, thus positively influencing the municipal and regional environment of the seaports, the environment of the most important Polish seaports included.

2. However, at the same time the tendencies towards increasing the importance of services, complimentary to the primary operations of port industry plants, will grow.

3. If the handling and storage potential is not fully exploited in order to meet the individual needs of particular entities, they will provide such services to external entities. The operations performed for external entities can become an important component of the strategy for diversifying the operations of particular industrial entities.

4. The industrial plants with a substantial land reserve will also try to attract investors interested in launching their business operations, which are primarily services, on the port land.

5. In the case of the examples as analyzed in this article, including the Baltchem - a Szczecin-based company - and the Siarkopol Gdańsk, the services provided for external entities will be developed and at the same time their industrial operations will be discontinued.

6. By making its decision to lease out and develop its port land in Kędzierzyn Koźle, the Baltchem has set a new direction in the development of services provided by the former port industry plants, i.e. the handling and storage services provided in the supply base of seaports. 


\section{References}

Alfa Terminal Szczecin, 2015, www.alfaterminal.pl.

Baltchem, 2015, http://baltchem.com.pl.

Baltchem, 2013, internal resources.

Fosfory, 2015, www.fosfory.pl .

Grupa Azoty Z.Ch. Police, 2015, http://zchpolice.grupaazoty.com/pl.

Jarmarczysk P., A. Rzempała., Użeglownienie Odrzańskiej Drogi Wodnej warunkiem rozwoju gospodarczego, 2nd International Maritime Congress in Szczecin, June 12-14, 2014.

Karpiński A., Przemiany strukturalne w procesie transformacji Polski 1989-2003-2025, Oficyna Wydawnicza SGH, Warszawa 2008.

Klamut M., Ewolucja struktury gospodarczej w krajach wysoko rozwiniętych, Wyd. Akademii Ekonomicznej im. Oskara Langego, Wrocław 1996.

Kołowski A., J. Wysocki., Zmiany strukturalne w gospodarce polskiej, Demografia przedsiębiorstw, 2012, www.praktycznateoria.pl/zmiany-w-strukturze/.

Kotowska I., M. Mańkowska, M. Pluciński., Uwarunkowania i kierunki aktywizacji obszaru portowego zlokalizowanego na pótnoc od terminalu morskiego portu Police, Szczecin 2009 (unpublished).

Kotowska I., M. Pluciński., Port morski Police a sieci logistyczne - analiza i ocena kierunków rozwoju portu, „Logistyka” 2007, No. 1.

Krono-Chem, 2013, internal resources.

Luks K., Port Elbląg w polityce morskiej państwa, Wyd. EUH-E, Elbląg 2009.

Ładysz J., Polityka strukturalna Polski i Unii Europejskiej, PWN, Warszawa 2008.

Mańkowska M., Możliwości obstugi wybranych grup ładunkowych w porcie morskim Police, Zeszyty Naukowe US No. 589, Ekonomiczne Problemy Usług No. 49, Europa Bałtycka. Przeszłość, teraźniejszość, nowe wyzwania, ed. A.S. Grzelakowski, P. Niedzielski, M. Pluciński, Wydawnictwo Naukowe Uniwersytetu Szczecińskiego, Szczecin 2009.

Pluciński M., Polskie porty morskie w zmieniajacym się otoczeniu zewnętrznym, CeDeWu, Warsaw 2013.

Siarkopol Gdańsk, 2015, www.siarkopol.gda.pl .

Siarkopol Gdańsk and Siark-Port, 2013, internal resources.

Zarzecki, D. (ed.)., Strategia rozwoju morskiego portu Police w latach 2006-2020, Police 2006.

Zakłady Nawozowe Fosfan, 2013, internal resources.

Zakłady Nawozowe Fosfory, 2013, internal resources. 


\title{
TRANSFORMACJA ZAKŁADÓW PRZEMYSŁU PORTOWEGO W KIERUNKU WZROSTU ZNACZENIA DZIALALNOŚCI USŁUGOWEJ. STUDIUM PRZYPADKÓW
}

\begin{abstract}
Streszczenie
Tradycyjna grupę zakładów przemysłu portowego, funkcjonujących w portach morskich, w tym w największych portach morskich Polski, stanowią zakłady importujące drogą morską tanie surowce do produkcji. Mając bezpośredni dostęp do transportu morskiego, wykorzystują one tzw. efekt skali. Zakłady te w okresie po rozpoczęciu w Polsce transformacji systemowej przechodziły przeobrażenia organizacyjno-własnościowe i funkcjonalne. Jednym $\mathrm{z}$ najważniejszych kierunków tych przekształceń był wzrost znaczenia działalności usługowej w funkcjonowaniu tych zakładów. O ile w przypadku zakładów nawozowych z Polic, Gdańska i Szczecina można zaobserwować rozwój działalności usługowej, realizowanej zarówno na własne potrzeby, jak i na rzecz podmiotów zewnętrznych, przy jednak nadal dominującej działalności przemysłowej, w przypadku pozostałych analizowanych w artykule zakładów przemysłowych ulokowanych w polskich portach morskich, doszło do zmiany profilu realizowanej działalności gospodarczej z przemysłowego na typowo usługowy. Stopniowo rezygnowały one z prowadzenia działalności produkcyjnej, a w miejsce przeładunków realizowanych jedynie na własne potrzeby rozwinięto działalność usługową na rzecz klientów zewnętrznych i nowych ładunków. Proces ten objął Baltchem, Siarkopol Gdańsk oraz dawną Hutę Szczecin. Należy przewidywać, iż w przyszłości w polskim sektorze przemysłu portowego będą się umacniały tendencje do wzrostu znaczenia:

- działalności usługowej jako działalności komplementarnej w stosunku działalności przemysłowej,

- działalności usługowej realizowanej na rzecz podmiotów zewnętrznych,

- zjawiska lokowania inwestorów zewnętrznych (głównie z sektora usług) na niewykorzystywanych na własne potrzeby terenach portowych,

- zastępowania działalności przemysłowej działalnością usługową.
\end{abstract}

Słowa kluczowe: przemysł portowy, usługi portowe, transformacja systemowa 


\section{THE COMPLEMENTARY/ \\ SUBSTITUTE TRANSPORT BRANCHES \\ AND HINTERLAND OF SEAPORTS}


